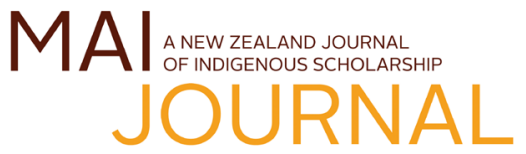

DOI: 10.20507/MAIJournal.2020.9.3.9

\title{
STUDENT VOICE
}

\section{Learning paangarau in a Maaori-medium modern learning environment}

\author{
Ngaarewa Haawera* \\ Leeana Herewini ${ }^{\dagger}$
}

\begin{abstract}
Maaori-medium educators are deeply committed to the revitalisation of tikanga and te reo Maaori in order to enhance the cultural setting in which aakonga learn and kaiako teach. This article originates from a project which set out to explore the teaching, learning and achievement in paangarau of learners in a Maaori-medium puna maatauranga kiritoa/modern learning environment (PMK/MLE) located in a small town in Aotearoa New Zealand. In this two-year study, a total of 106 year 4-6 aakonga were supported to consider the teaching and learning of paangarau in their PMK. This article reports the findings drawn from the analysis of data collected from two semi-structured focus group interviews with a total of 15 year 4-6 aakonga; one was held in September 2018 and the other in July 2019. The findings reveal insights into the types of pedagogy and tasks in paangarau that can increase opportunities for children's collaboration, self-management and engagement.
\end{abstract}

\section{Keywords}

student voice, paangarau, Maaori-medium, pedagogy, collaboration, digital technology

\section{Introduction}

Article 12 of the United Nations Convention on the Rights of the Child (UNCRC, 1989) states that all children have the right to express their views in regard to matters that affect them and that those views are to be taken seriously when making future decisions (United Nations Human Rights Council, 2014). Listening to children's views can alert educators to consider important ideas for supporting their learning (Bland \& Sharma-Bryer, 2012; Cheeseman \& Michels, 2013; Flutter \& Rudduck, 2004; Kangas, 2010; Quaglia \& Fox, 2018; Robson \& Mastrangelo, 2017). Flutter and Ruddick (2004) articulate that a key benefit of eliciting and acting upon student voice is that it can change educators' perceptions of pupils and the pupil role while also conveying a crucial message to children that they can act to influence their immediate world and eventually their wider world. Students who feel they have a voice regarding their education are more likely to engage in and take ownership of their learning (Quaglia \& Fox, 2018). In conjunction with this, a commitment from teachers is also required to listen and learn from their students. In this way student voice becomes an integral part of all aspects of the school and how it functions.

A high-quality learning environment seeks 
to support children's learning and their overall development (Claxton, 2008; Davies et al., 2016; Ministry of Education [MoE], 2007, 2008). Schools are expected to provide learning environments that enhance the development of not only students' cognitive and physical success but also their cultural, social and emotional wellbeing. Aligned with this, powerful learning environments will also offer learners numerous interesting and challenging opportunities across the curriculum (Claxton, 2008).

A quality learning environment for Maaorimedium learners includes a strong focus on providing access to a high standard of te reo Maaori and culturally relevant teaching and learning experiences (MoE, 2008; Nepe, 1991; Smith, 1999). Research also articulates the critical importance of teacher-learner relationships for Maaori learners (Bishop et al., 2003; Cavanagh et al., 2012; Hawk et al., 2002). Their research highlights that when a positive relationship exists, student motivation and participation increases, resulting in more effective learning. Hawk et al. (2002) further state that an absence of such a relationship can be a barrier to learning for some students. Maaori-medium kaiako are charged with managing an environment where all of these factors are considered and addressed (Bishop et al., 2003; MoE, 2008).

With regard to mathematics learning, listening to children reveals that they are able to identify factors which can impact on the development of their thinking (Abercrombie, 2015; Anthony \& Walshaw, 2007; Attard, 2012; Hawera \& Taylor, 2013; O'Shea, 2009). These factors include teachers providing relevant, worthwhile and challenging tasks; the promotion of a caring environment; encouraging the communication of mathematical ideas; and the integration of appropriate materials and tools to support the development of conceptual understanding. While the provision of a wellresourced and thoughtfully constructed physical environment is appreciated, student success is still largely attributed to teacher knowledge and skills, and how they might seek to organise appropriate and meaningful learning experiences (Anthony \& Walshaw, 2007; Bisset, 2014; Walshaw, 2012).

Interaction and communication between kaiako and aakonga and between aakonga and aakonga is an expected feature of a paangarau learning environment. The discussion and debating of ideas is a critical component and key strategy for understanding and learning key mathematical concepts (Brown et al., 2009; R. Hunter et al., 2018).
Kaiako intent on developing meaningful talk to support children's mathematical learning, while maintaining appropriate noise levels in a new learning environment such as a puna maatauranga kiritoa/modern learning environment (PMK/MLE) can find this process challenging. A noisy environment hinders learning for all learners in any space, especially for learners who have hearing challenges (Benade, 2019).

\section{Historical development of learning environments}

Teaching large groups of children in more open spaces is not a new idea to Aotearoa New Zealand. Examples of such spaces organised for learning with a group of kaiako "team teaching" were evident during the latter half of the 20th century (Wright, 2018). While there has been a return to aspects of this model during recent years, teachers providing a more flexible and digitally connected learning environment for aakonga has become a key focus (Wright, 2018). These MLEs have been strongly promoted as sites for developing students as 21 st-century learners who need to acquire skills for collaboration, innovation and problem solving (Benade, 2019; Bolstad et al., 2012).

"Modern learning environment" was the original term drawn upon to describe a large, open space with a number of students and teachers sharing a teaching and learning environment. "MLE" has since been replaced by ILE (innovative learning environment) or FLE (flexible learning environment); however, all are still used interchangeably. The Organisation for Economic Co-operation and Development (2017) describes an ILE as "an organic whole embracing the experience of organised learning for given groups of learners" p. 16.

In an MLE, the same ideas espoused for quality mathematics learning are acknowledged and pursued for enactment. Although the flexibility of spaces in large modern buildings is advocated as most suitable for learners in a complex 21stcentury society (MoE, 2014), it is how teachers use that space that is important for student achievement. Bisset (2014) states that "the effectiveness of the MLE is largely determined by the ability of the staff and community to support and enact the intangible, pedagogical changes that are needed to establish their vision" p. 1. In Aotearoa New Zealand there remains also a need to provide clear and strong evidence that student achievement is much improved in an MLE.

Research findings also note the importance of MLEs striving to provide personalised learning by offering aakonga choices, not only about what, 
where and with whom they might learn, but also how that might occur. Teachers are charged with promoting diverse ways of teaching and learning that demand greater flexibility, innovation, openness and collaboration than ever previously required in the New Zealand schooling environment (Bisset, 2014; MoE, 2014; Murphy, 2016; Osborne, 2013; Wright, 2018).

Self-management is a key idea also embedded in the ideals promoted by the national documents for both Maaori-medium and English-medium settings, Te Marautanga o Aotearoa (MoE, 2008) and the New Zealand Curriculum for Englishmedium Teaching and Learning in Years 1-13 (MoE, 2007), in which learners are associated with developing skills regarding self-motivation, self-direction and self-assessment. Wehmeyer et al. (2017) define self-direction as occasions when "the person makes or causes things to happen in her or his own life instead of someone else doing that" p. 295. This action of self-direction can encourage learners to be more self-motivated. The authors further discuss ideas of self-evaluation where students learn to monitor their progress by comparing their performance with a goal or outcome they have set. The development of such skills aligns with the pursuit of classrooms that "maximize student involvement and self-direction and minimize teacher-controlled actions" (Wehmeyer et al., p. 296).

In an age of rapid technological innovation, the traditional learning space of buildings or physical area of the school has been challenged. Boundaries dictating where learning may occur have been extended (Kangas, 2010; MoE, 2007, 2014; H. Thomas, 2010). The affordances of digital technologies for assisting children's learning in mathematics has also been espoused for some time (Calder, 2009, 2011; Chval \& Hicks, 2009; Ingram et al., 2015; Seeley et al., 2005; Zevenbergen \& Lerman, 2004). Utilising digital technologies can impact on how students engage with tasks and assist them to consider mathematics in alternative ways (Calder, 2009, 2011; Ingram et al., 2015; Northcote, 2011). Te Marautanga o Aotearoa (MoE, 2008) recognises the importance of encouraging children's use of information and communications technology (ICT) to enhance children's learning in the 21st century and clearly placed this expectation on Maaori-medium educators. Currently the hangarau learning area in Te Marautanga o Aotearoa has been revised to strengthen the teaching and learning of hangarau matihiko content in all kura from 2020. The success, however, of using digital technologies for mathematics learning in Maaori medium is variable (Allen, 2017).

\section{Methodology}

Kaupapa Maaori methodology combined with action research was selected as an appropriate foundation for facilitating the overall research process (McAteer, 2013; Smith, 1999). Kaupapa Maaori research methodology recognises the legitimacy of te ao Maaori with its own language and culture while striving to validate and support the aspirations of each individual whaanau, hapuu, iwi and kura (Smith, 1999). It acknowledges the strengths of Maaori in their contexts and encourages the maintenance of respectful relationships to assist in the evolution of further culturally embodied narratives (Smith, 1999).

\section{Method}

This article reports the findings drawn from the analysis of data collected from two semi-structured focus group interviews, one held in September 2018 and another in July 2019. A total of 15 year 4-6 aakonga in a Maaori-medium PMK/MLE in a kura in a small town in Aotearoa New Zealand participated. Informed and written consent for the children's participation in the research had been granted by their parents or guardians after ethical approval from the University of Waikato Human Research Ethics Committee had been gained (FEDU018/18). Children were interviewed in a room at the school away from their MLE by both researchers. Interview responses were captured on a digital device and the main points later transcribed for analysis (Table 1). Thematic analysis supports the presentation of findings as a story, and was used to identify key themes from the interviews with aakonga (J. Thomas \& Harden, 2008).

TABLE 1 Number of aakonga interviewed at each year level

\begin{tabular}{lllll}
\hline & Year 4 & Year 5 & Year 6 & Total \\
\hline 2018 & 4 & 2 & 2 & 8 \\
2019 & 1 & 1 & 5 & 7 \\
\hline
\end{tabular}


Data discussed in this article relate to children's responses to the following questions:

Peewhea oo koutou whakaaro mo te ako paangarau ki roto i teetehi ruuma nunui?

(What do you think about learning paangarau in this big room?)

I kii mai ngaa kaiako, e hiahia ana raatou kia pai ake te waa ako paangarau maa koutou engari kaare raatou i te moohio me peewhea? He whakaaro oo koutou moo raatou?

(Teachers have said that they would like to improve your learning time for paangarau but don't know how. Do you have any suggestions for them?)

\section{Findings}

The findings presented here are linked to particular features of a quality learning environment. They include ideas about pedagogical practice as well as thoughts regarding the use of digital technologies for learning paangarau. Aakonga were able to describe ways in which their learning of paangarau could be improved.

\section{Pedagogy}

One aakonga commented, "Tuhia he tauira maa te papa maa.... Kaare raatou [ngaa tamariki] e moohio me aha raatou" ("Write examples on the whiteboard. . . . They [aakonga] don't know what they are required to do") (aakonga M, 2018). Another interesting idea was shared by one child: "Kaua e whoatu he mahi anoo meenaa ka mutu ngaa mahi" ("Don't keep giving us more work when we have finished the work") (aakonga T, 2018).

In both focus groups one aakonga mentioned they would like their paangarau work to be more challenging:

Pai kia uaua te mahi.

(It would be good if the work was more challenging.) (akonga AH, 2018)

Me uaua ake.

(Work should be more challenging.) (aakonga T, 2019)

\section{Learning in this big room}

The MLE model was introduced and implemented in the kura during 2017. The nature of sharing a large room means that the movement of some aakonga during learning time may cause them to be in close proximity to other learners, who can become distracted. As one participant commented, "Ka koorero mai teetahi atu, mai teetahi roopuu, ka kohete a whaea i a koe" ( "When someone from another group talks to me, the teacher growls") (aakonga A, 2019). The same aakonga added in English, "Others are talking and you are trying to do work."

Other ideas mentioned included:

Kotahi rau ngaa tangata, kaare e taea e koe te focus.

(There are 100 people, you cannot focus.) (aakonga $\mathrm{AH}, 2018)$

Me noho ki teetahi kaiako.

(I prefer to stay with one kaiako.) (aakonga J, 2019)

He pai-i te mea ka taea te mahi tahi.

(It is good-because you can work with others.) (akonga D, 2019)

\section{Level of noise}

Concern about the level of noise was mentioned by only one participant of the focus groups: "Tino noisy teeraa atu taha" ("That side is really noisy") (aakonga T, 2018). However, in the second focus group it became evident that noise during the learning of paangarau time had become more of an issue for some. Comments from four of the seven tamariki included:

He haamama.

(There's shouting.) (aakonga N, 2019)

He hoihoi ... haaparangi.

(It’s noisy ... . shouting.) (aakonga T, 2019)

Uaua te rongo. ... Ka haaparangi tooku kaiako.

(It's difficult to hear . . . My kaiako shouts.) (aakonga A, 2019)

Kaare e pai ki a au te haamama ngaa tamariki, ngaa kaiako hoki.

(I don't like it when children are shouting and kaiako too.) (aakonga J, 2019)

\section{Hangarau matihiko}

Access to frequent use of digital technologies for exploration of ideas is promoted as a feature of an MLE (Benade, 2019). In the 2018 focus group, two out of the eight aakonga requested more use of Chromebooks:

He pai te taakaro ki ngaa Chromebooks. 
(I like playing on Chromebooks.) (aakonga M, 2018)

He pai te taakaro ki runga ipapa, Chromebooks.

(I like playing on iPads, Chromebooks.) (aakonga, 2018)

In the 2019 focus group, all seven aakonga declared their interest in having more access to hangarau matihiko. They described their current access as follows:

I eetehi waa-Roadblock [he kemu rorohiko/ online].

(Sometimes-Roadblock [online computer game].) (aakonga M, 2019)

Pai te mahi Kahn Academy [he hootaka aa ipurangi].

(I like Kahn Academy [an online education platform].) (aakonga, T, 2019)

Inaa ka mutu ka taea te taakaro i runga i ngaa Chromebooks.

(When we finish we are able to play on Chromebooks.) (aakonga J, 2019)

Calculator. (aakonga J, 2019)

Math Playground [an online education platform]. (akonga P, 2019)

Ka tuhia a Whaea ka haere ki te mahi Google Docs ka tiikina atu Google Classroom mai Google Drive.

(Teacher prepares the work and we go to Google Docs in Google Classroom on Google Drive.) (aakonga A, 2019)

\section{Discussion}

\section{Pedagogy}

Teacher pedagogical practice is an important factor affecting children's learning in paangarau (Anthony \& Walshaw, 2007; Walshaw, 2012). In this part of the study, aakonga were asked about what aspects of teacher pedagogy they considered can have an impact on their learning of paangarau. In busy classrooms, some aakonga may require a range of scaffolds that detail what is expected of them to explore tasks. Aakonga reported that giving verbal instructions was the main pedagogical approach of kaiako for outlining expectations of tasks. It is clear, however, that some aakonga would prefer a range of media to stimulate their mathematical thinking so that they can engage successfully with the paangarau tasks. As well as the use of physical manipulatives and aural cues, the use of recorded examples (either digital, paperbased or via a whiteboard) that integrate similar mathematical understandings can be helpful for assisting some learners to understand what is being taught.

Preparing tasks that demand student engagement includes the consideration of a broad range of connected ideas. Deep reflection about the tasks, the planning, the delivery, the ideas for learning, the gathering of evidence, possible judgements regarding progress, and next learning steps are all part of the teaching and learning process (Anthony \& Walshaw, 2007). These reflections can add clarity for kaiako about the complexity and demands of a task and enable them to better assist aakonga to understand that being given and doing more work is not unnecessary added work but an inherent part of the task itself. Kaiako can also use these occasions to gain a greater awareness of task progression and how a task may be suitably extended to challenge those requiring further learning. Such a process may also in fact reveal opportunities for independent learning and self-management by aakonga, which can be negotiated and agreed upon with kaiako.

This notion of self-management and teacher management for learning can be linked to teacher pedagogy (Anthony \& Walshaw, 2007; Wehmeyer et al., 2017). Greater attention to strategies for managing learning for some learners may be required in large spaces like an MLE with over 100 aakonga. Aspects such as the level of noise will require more thought and monitoring due to research indicating that learning mathematics as a solitary endeavour is not deemed to be the most productive or effective way for many students. The idea that learning mathematics should involve groups of learners supporting each other by discussing ideas and challenging each other as they reason their way through the problem-solving process has long been advocated (Attard, 2012; Franke et al., 2007; J. Hunter, 2009; Lampert \& Cobb, 2003; Yackel \& Cobb, 1996; YoungLoveridge et al., 2005). By talking, listening and sharing ideas and actively exploring mathematical concepts with their peers, in groups or whole-class situations, children learn to make connections between concrete and abstract thought. This is essential for mathematical understanding to occur.

Strategies for negotiating appropriate levels of noise will involve deliberate planning by kaiako within the MLE as well as careful discussion with aakonga so that boundaries and areas can be 
agreed upon. Noise level impacts on how much some children can hear as well as affecting their focus and engagement with the tasks. A discussion about noise is an opportunity for aakonga and kaiako to negotiate and agree on how to initiate and manage classroom talk for learning (R. Hunter et al., 2018). When invited, aakonga are more than capable of suggesting ideas about optimising conditions for their learning (Bland \& Sharma-Brymer, 2012; Kangas, 2010; Office of the Children's Commissioner, 2018). In an MLE situation it may be that there are designated quiet zones or breakout rooms where aakonga are able to work in reduced noise zones (Murphy, 2016; Osborne, 2013). Noise management needs to be planned for, and teaching spaces require a variety of appropriate materials to absorb or block different sounds (Mealings et al., 2015; MoE, 2015).

\section{Collaboration}

One of the key tenets supporting the introduction of MLEs to Aotearoa New Zealand is that learners will gain more opportunities to collaborate when exploring tasks (Bisset, 2014; Murphy, 2016). They are expected to develop skills in communicating and working with others, which is considered necessary for successful citizenship: "In the 21st century, citizens need to be able to apply knowledge to solve complex problems, often in cross-disciplinary and collaborative settings" (21st Century Learning Reference Group, 2014, pp. 7-8). The absence of greater appreciation by the aakonga in this study of the benefits of collaborating with others in a large MLE space indicates a need for those advantages to be made explicit.

Collaboration when learning paangarau also includes that which occurs between aakonga and kaiako. While it is pleasing that only one child out of 15 made a comment over the two focus groups about preferring to stay with one teacher, it does provide a moment to pause and consider the significance of such a comment. Teacher-pupil relationships are an important factor for children's learning (Cavanagh et al., 2012; Hawk et al., 2002; Jeffrey et al., 2013) and for most children in this data set working with different kaiako for learning paangarau does not appear to be an issue. Kaiako in this study are to be commended for ensuring such bonds are robust and act as a support for learning. However, with some MLEs striving to provide optimal learning conditions for large groups of students, the number of teachers that a child has to develop a meaningful relationship with may be problematic. In such settings the emotional wellbeing of every child deserves consideration, as does the time and energy to be expended in this area by teachers.

\section{Hangarau matihiko}

Hangarau matihiko are purported to "play an increasingly critical role in shaping and supporting an effective 21st-century curriculum" (MoE, 2014 , p. 4). Such technologies have been shown to be an effective tool to support aakonga engagement (Attard, 2012; Calder, 2009, 2011; Ingram et al., 2015) and need to be an integral part of the teaching and learning process for paangarau. The benefits of utilising digital devices include enabling aakonga to take charge of their own learning, which may occur anywhere at any time. While these learners expressed an appreciation of engaging with devices during their paangarau learning time, it would appear that such engagement is restricted largely to "playing". Evidence of more substantial integration of digital technologies for exploring key paangarau ideas is limited. The effective use of hangarau matihiko requires knowledge and careful deliberation so as to be fit for purpose and appropriate for learners.

One tension facing kaiako of paangarau is the inequitable provision of apps and digital learning objects in te reo Maaori. A plethora of such resources in English has been made available by the MoE for some time. Ensuring aakonga are part of a quality reo Maaori environment using digital technologies for sharing and learning ideas requires greater resourcing in te reo Maaori by the MoE. Such action needs to align with more confident and knowledgeable teachers (Allen, 2017). The inclusion of the hangarau matihiko content within the hangarau learning area of $T e$ Marautanga o Aotearoa (MoE, 2008), which many kura are being supported to engage with, is one attempt to assist kaiako and aakonga in this area. More is required for Maaori-medium settings now.

\section{Concluding remarks}

This article has focused on listening to aakonga about the teaching and learning of paangarau in their MLE/PMK. While the findings are limited to two small groups of children in a particular context, they do reveal valuable and thoughtprovoking ideas for kaiako interested in examining how teaching and learning is occurring in their MLE/PMK. Although the development of selfmanagement, collaboration and digital technology knowledge and skills by learners in schools in Aotearoa New Zealand is not a new idea, it is something that needs to urgently become a reality. 
Failing to understand that urgency and act on it will deprive another generation of Maaori of optimal educational success and citizenship.

The original research behind this article grew out of an interest and desire to explore the transition process for kaiako and aakonga from single-cell classrooms to an MLE/PMK. The findings here are focused on pedagogy, collaboration and hangarau matihiko. While aspects of these findings might be similar to those found in some single-cell classrooms, their scale and complexity is exacerbated markedly by the increased size, physical plan and greater expectations of the more flexible teaching and learning processes within an MLE. Leadership within the kura in this research saw the benefits of fostering MLE experiences, with individual kaiako teaching to their strengths.

The MLE environment in Aotearoa New Zealand is fast becoming the norm. Its implementation demands close scrutiny so that the affordances they are supposed to offer each community are realised. For kaiako seeking increased engagement and success for children learning paangarau in Maaori medium, we must be vigilant to ensure we have not just found another environment for them that doesn't work. These aakonga have spoken! Are we listening?

\section{Acknowledgements}

E aku nui, e aku rahi, teenei te mihi maioha ki a koutou katoa, ngaa aakonga, ngaa kaiako, te tumuaki, e whai waahi mai ana ki te rangahau. Mei kore ake oo koutou whakaaro nui hei aarahi i te rangahau nei kaare i tutuki pai. E kore ngaa mihi e mimiti. Ka mihi hoki ki te Teaching and Learning Research Initiative i too koutou tuku puutea mai moo te rangahau.

\section{Glossary}

$\begin{array}{ll}\begin{array}{l}\text { aakonga } \\ \text { hangarau } \\ \text { hangarau matihiko } \\ \text { hapuu }\end{array} & \begin{array}{l}\text { student } \\ \text { technology } \\ \text { digital technologies } \\ \text { subtribe } \\ \text { tribe } \\ \text { kaiako }\end{array} \\ \text { kura } & \begin{array}{l}\text { Maaori-medium school } \\ \text { Maaori }\end{array} \\ \text { Indigenous peoples of New } \\ \text { Zaangarau } & \text { mathematics } \\ \text { te ao Māori } & \text { the Māori worldview } \\ \text { te reo Maaori } & \text { the Maaori language } \\ \text { tikanga } & \text { protocol, custom } \\ \text { whaanau } & \text { family }\end{array}$

\section{References}

21st Century Learning Reference Group. (2014) Future-focused learning in connected communities. https://www.education.govt.nz/assets/Documents/ Ministry/Initiatives/FutureFocusedLearning 30May2014.pdf

Abercrombie, C. (2015). Teaching mathematics through a mixed ability approach. In R. Averill (Ed.), Mathematics and statistics in the middle years: Evidence and practice (pp. 99-115). NZCER Press.

Allen, P. (2017). Using mobile technology to encourage mathematical communication in Māori medium pāngarau classrooms. Teachers and Curriculum, 17(2), 85-88. https://doi.org/fkwf

Anthony, G., \& Walshaw, M. (2007). Effective pedagogy in mathematics/pāngarau: Best evidence synthesis iteration (BES). Ministry of Education.

Attard, C. (2012). Applying a framework for engagement with mathematics in a primary classroom. Australian Primary Mathematics Classroom, 17(4), 22-27.

Benade, L. (2019). Flexible learning spaces: Inclusive by design? New Zealand Journal of Educational Studies, 54(1), 53-68. https://doi.org/gg6dpq

Bishop, R., Richardson, C., Tiakiwai, \& Berryman, M. (2003). Te Kotahitanga: The experiences of Year 9 and 10 Māori students in mainstream classrooms. Ministry of Education.

Bisset, J. (2014). The move to modern learning environments in New Zealand secondary schools: Step forward or smokescreen? [Master's thesis, Unitec Institute of Technology]. Research Bank. https:// hdl.handle.net/10652/2700

Bland, D., \& Sharma-Brymer, V. (2012). Imagination in school children's choice of their learning environment: An Australian study. International Journal of Educational Research, 56, 75-88. https://doi. org/fkbn

Bolstad, R., Gilbert, J., McDowall, S., Bull, A., Boyd, S., \& Hipkins, R. (2012). Supporting future-oriented learning \& teaching: A New Zealand perspective. Ministry of Education.

Brown, C. L., Cady, J. A., \& Taylor, P. M. (2009). Problem solving and the English language learner. Mathematics Teaching in the Middle School, 14(9), 532-539.

Calder, N. (2009). How digital technologies might influence the learning process. In R. Averill \& R. Harvey (Eds.), Teaching secondary school mathematics and statistics: Evidence-based practice (Vol. 1, pp. 131-144). NZCER Press.

Calder, N. (2011). Processing mathematics through digital technologies: The primary years. Sense Publishers. https://doi.org/fzpkd2

Cavanagh, T., Macfarlane, A., Glynn, T., \& Macfarlane, S. (2012). Creating peaceful and effective schools through a culture of care. Discourse: Studies in the Cultural Politics of Education, 33(3), 443-455. https://doi.org/fkbp

Cheeseman, S., \& Michels, D. (2013). Listening to children in order to capture potential for learning. 
Australian Primary Mathematics Classroom, 18(2), 3-8.

Chval, K. B., \& Hicks, S. J. (2009). Calculators in K-5 textbooks. Teaching Children Mathematics, 15(7), 430-437.

Claxton, G. (2008). What's the point of school? Rediscovering the heart of education. Oneworld.

Davies, S., Janus, M., Dukub, E., \& Gask, A. (2016). Using the Early Development Instrument to examine cognitive and non-cognitive school readiness and elementary student achievement. Early Childhood Research Quarterly, 35(2), 63-75. https://doi.org/ f8npkw

Flutter, J., \& Rudduck, J. (2004). Consulting pupils: What's in it for schools? Routledge. https://doi. org/dwfpvp

Franke, M. L., Kazemi, E., \& Battey, D. (2007). Mathematics teaching and classroom practice. In F. K. Lester (Ed.), Second handbook of research on mathematics teaching and learning (pp. 225-256). Information Age.

Hawera, N., \& Taylor, M. (2013). Children's views about geometry tasks in Māori medium schools: Meeting Ngā Whanaketanga Rumaki Māori pāngarau (National Standards in mathematics). SET: Research Information for Teachers, 3, 37-46. https://doi.org/fkbr

Hawk, K., Cowley, E., Hill, J., \& Sutherland, S. (2002). The importance of the teacher/student relationship for Maaori and Pasifika students. SET: Research Information for Teachers, 2, 44-49. https://doi. org/fkbs

Hunter, J. (2009). Developing a productive discourse community in the mathematics classroom. New Zealand Mathematics Magazine, 46(1), 1-12.

Hunter, R., Hunter, J., Anthony, G., \& McChesney, K. (2018). Developing mathematical inquiry communities: Enacting culturally responsive, culturally sustaining, ambitious mathematics teaching. SET: Research Information for Teachers, 2, 25-32. https://doi.org/fkbt

Ingram, N., Williamson-Leadley, S., Bedford, H., \& Parker, K. (2015). Using Show and Tell tablet technology in mathematics. In R. Averill (Ed.), Mathematics and statistics in the middle years: Evidence and practice (pp. 18-34). NZCER Press.

Jeffrey, A. J., Auger, R. W., \& Pepperell, J. L. (2013). “If we're ever in trouble they're always there": A qualitative study of teacher-student caring. Elementary School Journal, 14(1), 100-117. https://doi.org/ f46zzw

Kangas, M. (2010). Finnish children's views on the ideal school and learning environment. Learning Environments Research, 13(3), 205-223. https:// doi.org/d9b6dq

Lampert, M., \& Cobb, P. (2003). Communication and language. In J. Kilpatrick, W. G. Martin, \& D. Schifter (Eds.), A research companion to principles and standards for school mathematics (pp. 237-249). National Council of Teachers of Mathematics.

McAteer, M. (2013). Action research in education. SAGE.
Mealings, K., Dillon, H., Buchholz, J., \& Demuth, K. (2015). An assessment of open plan and enclosed classroom listening environments for young children: Part 1-Children's questionnaires. Journal of Educational, Pediatric \& (Re)Habilitative Audiology, 1, 3-19.

Ministry of Education. (2007). The New Zealand Curriculum: For English-medium teaching and learning in years 1-13. Ministry of Education.

Ministry of Education. (2008). Te Marautanga o Aotearoa. Ministry of Education.

Ministry of Education. (2014). Shaping educationFuture directions. http://shapingeducation.govt. nz/2-0-future-direction-of-education/propertyprogramm

Ministry of Education. (2015). Designing quality learning spaces. https://www.education.govt. $\mathrm{nz} / \mathrm{school} /$ property-and-transport/projectsand-design/design/design-standards/designingquality-learning-spaces/

Murphy, C. (2016). Making the shift: Perceptions and challenges of modern learning practice [Master's thesis, University of Waikato]. Research Commons. https://hdl.handle.net/10289/10523

Nepe, T. (1991). E hao nei e tenei reanga te toi huarewa tupuna: Kaupapa Māori, an educational intervention system [Master's thesis, University of Auckland]. ResearchSpace. http://hdl.handle. net/2292/3066

Northcote, M. (2011). Teaching with technology. Australian Primary Mathematics Classroom, 16(3), 29-32.

Office of the Children's Commissioner. (2018). He manu kai mātauranga: He tirohanga Māori. Experiences of tamariki and rangatahi Māori. https://www.occ. org.nz/assets/Uploads/Experiences-of-Maori2.pdf

Organisation for Economic Co-operation and Development. (2017). The OECD handbook for innovative learning environments. https://doi.org/ d9tp

Osborne, M. (2013). Modern learning environments. Core Education. https://core-ed.org/assets/PDFs/ Innovative-Learning-Environments.pdf

O'Shea, H. (2009). The ideal mathematics class for grades 5 and 6: What do the students think? Australian Primary Mathematics Classroom, 14(2), 18-23.

Quaglia, R. J., \& Fox, K. M. (2018). Student voice: A way of being. Australian Educational Leader, 40(1), 14-18.

Robson, K., \& Mastrangelo, S. (2017). Children's views of the learning environment: A study exploring the Reggio Emilia principle of the environment as the third teacher. Journal of Childhood Studies, 42(4), 1-16. https://doi.org/fkbv

Seeley, C., Hagelberger, B., Schielack, J., \& Krehbiel, K. (2005). Using calculators in elementary school. Teaching Children Mathematics, 12(2), 52-53.

Smith, L. (1999). Decolonising methodologies: Research and Indigenous peoples. Zed Books.

Thomas, H. (2010). Learning spaces, learning environments and the "displacement" of learning. British 
Journal of Educational Technology, 41(3), 502511. https://doi.org/bjcrv9

Thomas, J., \& Harden, A. (2008). Methods for the thematic synthesis of qualitative research in systematic reviews. BMC Medical Research Methodology, 8(1). Article 45. https://doi.org/c73jf5

United Nations Convention on the Rights of the Child, November 20, 1989. https://treaties.un.org/pages/ ViewDetails.aspx? src=IND\&mtdsg_no=IV$11 \&$ chapter $=4 \&$ lang=en

United Nations Human Rights Council. (2014). Recommendations made to New Zealand during its second periodic review. https://www. hrc.co.nz/files/5514/2406/1354/List-of-UPRrecommendations-made-to-New-Zealand.pdf

Walshaw, M. (2012). Teacher knowledge as fundamental to effective teaching practice. Journal of Mathematics Teacher Education, 15(3), 181-185. https://doi.org/fkbw

Wehmeyer, M. L., Shogren, K. A., Toste, J. R., \& Mahal, S. (2017). Self-determined learning to motivate struggling learners in reading and writing. Intervention in School and Clinic, 52(5), 295-303. https://doi.org/f95mrk
Wright, N. (2018). Becoming an innovative learning environment: The making of a New Zealand secondary school. Springer. https://doi.org/fkbx

Yackel, E., \& Cobb, P. (1996). Sociomathematical norms, argumentation, and autonomy in mathematics. Journal for Research in Mathematics Education, 27, 458-477. https://doi.org/fvkckp

Young-Loveridge, J. M., Taylor, M., \& Hawera, N. (2005). Going public: Students' views about the importance of communicating their mathematical thinking and solution strategies. In J. Higgins (Ed.), Findings from the New Zealand Numeracy Development project 2004 (pp. 97-106). Ministry of Education.

Zevenbergen, R., \& Lerman, S. (2004). Using ICT to support numeracy learning across diverse settings. In I. Putt, R. Faragher, \& M. McLean (Eds.), Mathematics education for the third millennium towards 2010. Proceedings of the 27th Annual Conference of the Mathematics Education Research Group of Australasia, Townsville, 27-30 June 2004 (Vol. 2, pp. 591-598). MERGA. 